SECTION 12. Geology. Anthropology. Archaeology.

Nishiaki Yoshihiro
Ph.D.
professor of the University Museum
University of Tokyo,
Tokyo, Japan

Hasanov Elnur Latif oglu

Ph.D. postgraduate, correspondent member of International Academy of Theoretical \& Applied Sciences, scholar of Ganja Branch of Azerbaijan National Academy of Sciences,

Ganja, Azerbaijan

el-hasanov@mail.ru

\title{
ABOUT ETHNO-ARCHAEOLOGICAL AND ANTHROPOLOGICAL RESEARCH OF SOME PREHISTORIC MONUMENTS OF GANJA
}

\begin{abstract}
In this scientific work for the first time have been researched the basic typical prehistoric monuments of Ganja. History of ethnographic-archaeological studying of these monuments also were investigated in this article.
\end{abstract}

Key words: Ganja, Azerbaijan, craftsmanship branches, prehistoric monuments, innovative methods and technologies

Ganja - an ancient center of urban culture with more than 4000 years history, that situated on the old Great Silk way, is rich with many historical and material-cultural monuments, which have their typical, unique trade and architectural characteristics. As a result of archaeological excavations and ethnographical researches in Ganja during various historical periods have been found different material-cultural monuments. Therefore, Ganja and its surrounding areas are considired as one of the richest territories of Azerbaijan from the historical-ethnographical and archaeological point of view.

During many centuries in this ancient scientific and cultural center have been formed and developed the handicraft, also architectural styles on the basis of wealthy traditions. Owing to development of centuries-old building and decorative-applied art traditions next to the common features of Arran architectural school, architecture of Ganja guarded some typical, unique skill and architectural characteristics:

Firstly, since the classical and Middle Ages periods in an old cultural and political center - Ganja city, have been built the public and dwelling buildings from the local baked red brick.

In Ganja, first scientist, who has given information about the rich epigraphic, ethnographic, archaeological, numismatic material-cultural patterns, was French researchers Dubua de Monpere. In 1834 on the way to Tiflis (Tbilisi) he came to Helenendorph (now Goygol) and found different black-colored ceramic plates and bronze patterns (objects), which showed, that an ancient city culture formed here. Also, many archaeological wares and material patterns, that have found by Zare, Morgan, Virkhov in that period, are reserved in Moscow, Petersburg, Drezden and in other European museums. V. Belk, who worked in Dashkesen, Gedabei copper minds, found here more than 300 monuments, which proved the ancient city culture of Ganja. Main parts of these items are reserved in Hamburg and Munich museums. E. Resler, who was the teacher in Ganja (Yelizavetpol) province in 1892-1903 years, on the basis of his researches around of Ganjachai (Ganja river) has found many materials, connected with the ancient history and culture of this city. Some parts of his material patterns are now reserved in Moscow and Saint-Petersburg museums. In 1896 A. 
Ivanovsky with the request of Moscow Archaeological Society has been sent to the province of Yelizavetpol for archaeological excavations. Here he has found the old city cemetery with 72 stone boxes graves and sent those materials to Moscow. Now these materials are kept in the Moscow History Museum.

In 1903-1914 years B.Rozendorf, who was working pharmacists in Helenendorph carried out scientific-researches throughout in the territory of Ganjachai, discovered extremely valuable historical materials in Ganjachai valley Helenendorph and Chovdar villages, also graves of the ancient stone boxes, which reflected the old urban culture. Information about his researches was published in St. Petersburg in 1906, on "Reports of the Imperial Archaeological Commission".

Mining engineer B.Sults, who worked in the region of Ganjachai in 1898-1903, an officer in the military service in Yelizavetpol in 1905 V.A.Skinder, mining engineer F.Lass in 1908, E.P.Paritsenmayer in 1910, and many foreign researchers found in area Ganjachai the existence of extremely valuable historical materials. Some examples of them are kept in the museum of Berlin.

As a result of archaeological investigations here were found samples of material culture that concerned to the stages of different history period. Today most of them are kept in various museums of the world. The flint tools, that found in Gillikdag workshop and camp around Ganja, ladle, give the reason to say, that people, who lived in this area in VII - VI millennium BC were the founders of the Late Stone Age culture. Archaeological investigations prove that in this period the main population of this region had sedentary lifestyle and were engaged with farming. In $\mathrm{V}$ millennium $\mathrm{BC}$ in Ganja region all known to us domestic animals were domesticated. This fact is approved with osteology remainders that were found during archaeological excavations [2]. In whole Ganja's traditions are leading to spiritual pureness, they are collection of the universe laws to perfection, way of nation. Ganja and its surrounded territory are also rich with different stones. Presentation of white and in mountain and Aran Karabakh and also lime, travertin and marble building stones in and around Ganja, pure white, a lot of colored aqats, chalsedons, viel, ametist, obsidian, aqats, crystal and other kind of rare colored stones in the river basins of Shahdaq Kecheldag, and other territories created favorable ground for developing in this ancient country from ancient times stone cutting, stone grind, stone polishing and for building great modern, columned, arched, circled and four- cornered buildings here. Among archaeological equipment there have been found two big boards from stone camel eyes. Base - columns, capitals, that are symbols of irreplaceable art, part of columns, different man monuments, masonry art symbols, that have Ganja, agriculture and religious meaning, especially grave monuments and phalluses, collections of different colored (red, brown, black, grey and other rare colored) stamps and symbols of decorations, that were found in Azerbaijan during archeological investigations prove it. The best samples of monuments, that concern to stone treatment are consists of column props, mill and gridding stones. In whole there were founded in and around Ganja a lot of samples, that concern to X century. They are consisting of stone figure, mills and column props. But stone equipment, found in Ganja prepared from mill and candlestick. Mill is usually prepared from volcanic, quartz, limestone and basalt. They used for grinding seed, millet, salt and for other aims [5-7].

Traditional textile of art of silk weaving products has a special place in Ganja. In the city formed two main method of silk treatment: 1. Spinning. 2.Winding. Also, historically the traditional art of saddle-making in Ganja developed in direction of cargo and passenger saddle making. Afterwards military, economic and transportation significance of horse was decrease, the demand for goods of saddle-making also was decrease. In the territory of Azerbaijan the oldest samples of wood treatment were found in the territory of ancient Ganja. Around Ganja area - in the region of Lake Goy-gol in the IV-III millennium BC have been discovered 
wooden thicker board, also wooden sugar bowl, that concern to the end of the II millennium $\mathrm{BC}$, found in Mingechevir pitcher grave are material evidences of science thoughts.

Have been discovered, that initial ceramic production in Ganja and its surrounding regions are belong to the VIII-VII millennium BC. In Ganja and its regions during centuries ceramic trade has following kinds: 1. Building ceramic materials. 2. Unglazed ceramic products. 3. Glazed ceramic products [3-7]. At the end we can say that, during many centuries in this ancient cultural and scientific center developed different branches of craftsmanship.

Yakov Hummel, who had German nationality and worked in Helenendorph (Goygol) in the secondary school biology teacher with the help of the student circle of the school during the archaeological researches on the right and left banks of Ganjachai has found valuable materials, that concern to the Bronze and Iron age. The value of found materials was so great, that here has been created in Regional Museum of Helenendorph in 1927.

As a result of his archaeological research, has revealed, that a great civilization existed in Ganja in the initial stages of the primary community structure.

In 1940 he published "Archaeological Essays". The work is carried out within the resources dedicated to the results of Ganjachai researches.

In 1961, in connection with the closure of regional museum of Khanlar (Goygol), all the exhibits of the museum were given to Ganja State Historical Museum named Nizami. We can say, that today, 15 thousand exhibits, found in the region of Ganjachai and that concern to the different historical periods were obtained by Y. Hummel.

Comparing Ganja with the culture in Egypt and and Babylon dating to the 5 century Strabon noticed that it's the best. Since its foundation and changing its location five times Ganja became one of the most favourable cities and that's why foreign in vaders always wanted to occupy it. To the ancient Turkish tribes name taken from the name of the city Ganja. At different stages of the history of the capital city of Ganja status while maintaining the traditions of the ancient statehood and independence was of great importance. The city is in the province of the Caliphate of the seventh century, the X century and Shaddadis capital of Arran, in the eleventh century Seljuk, was the twelfth and thirteenth centuries residence in Atabaylar state. Nizami and orientalist Bertels outstanding scientific-researches in 1139 Ganja was destroyed in the terrible earthquake of 300 thousand people. This fact has made the city's power and greatness again.

For comparison, it should be noted that most major European city, Paris XIII century 100 thousand, 40-50 thousand people lived in London. Sheikh Nizami, in his opinion, and it becomes clear that the names by the works, libraries, and the millennium Ganja based on a rich scientific and cultural environment existed. Should not forget that the great Nizami Ganjavi, Abul-Ula Ganjavi (XI, Mehseti Ganjavi, after Siti, Omar boy, after Abu Bakr, Abu Hafs Ganjavi, as Mirza Shafi could not provide grounds famous people. Their ancient traditions for the formation of with the historical, socio-economic and cultural environment was needed. Existence of such an environment in the city of Ganja and 4 thousand years of history has been identified. Because of any of the city became a center for science and culture from ancient traditions and a long-term cultural development is required.

The cradle of ancient science and culture Ganja is famous in the world with its unusual historical monuments because of development art and architecture traditions.

Already in the X century, the construction and Renaissance works in Ganja, turned this city into the one of the largest architecture center of Azerbaijan.

From that period till now in Ganja have been developing more than 30 craft areas, such as separate samples of selected pottery items, carpet weaving, jewelry, saddle-making, copper, were built a lot of tombs, which has no analogue, numerous mosques, bridges, kehriz (water supply systems), castles and towers, that prove, that local architectural traditions have a rich history [6-10]. 


\section{References:}

1. Guliyev F., Nishiaki Y. Excavations at the Neolithic settlement of Goytepe, in the middle Kura Valley, Azerbaijan, 2008-2009 / Proceedings of the 7th International Congress of the Archaeology of the Ancient Near East. Wiesbaden: Harrassowitz Verlag, 2012

2. Guliyeva N.M., Hasanov E.L. About ethnographic-archaeological research of some handicraft branches of Ganja during XIX - XX centuries / Progressive scientific explorations - 2012: Proceedings of the 8th International scientific-practical conference. Prague: Publishing House - Education and Science s.r.o., 2012

3. Azərbaycan etnoqrafiyası: 3 cilddə, I c., Bakı: Şərq-Qərb, 2007, 544 s.

4. Həsənov E.L. Gəncə İmamzadə türbəsi (tarixi - etnoqrafik tədqiqat). Bakı: Elm və təhsil, 2012, $268 \mathrm{~s}$.

5. The dawn of Art. Leningrad: Aurora Art Publishers, 1974, $196 \mathrm{p}$.

6. Hasanov E.L. Some innovation historic-ethnographical arguments about development of craftsmanship in Ganja / Science, Technology and Higher education: Proceedings of the 1st International scientific - practical conference. Westwood: Publishing office Accent Graphics communications, 2012, p. 485-491

7. Burton-Brown T. Excavations in Azerbaijan, 1948. London, 1951, 250 p.

8. Häsänov E.L. Die Gändschänischen teppiche von XIX - XX Jahrhundert als geschichtliche - ethnographische quelle / European Science and Technology (Die Europäische Wissenschaft und die Technologien): $2^{\text {nd }}$ International scientific conference. Bildungszentrum Rdk e. V. Wiesbaden, 2012, p. 26-27

9. Azərbaycan tarixi üzrə qaynaqlar. Bakı: Azərbaycan Universiteti nəşriyyatı, 1989, 328 S.

10. Smith B.William, Hasanov E.L. Importance of handicraft traditions in investigation of history of urban culture in Ganja // International scientific journal Theoretical \& Applied Science (Applied scientific research: Proceedings of the International scientific-practical conference. Belgrade, Serbia), 2013, № 11 (7), p. 61-66 